\title{
Petrology of the most recent eruption of Melbourne volcano, Antarctica: insights into evolution of the magma plumbing system
}

\author{
J.I. LEE ${ }^{1 *}$, M.J. LEE ${ }^{1}$, G.B.KIM ${ }^{2}$ AND P.R. KYLE ${ }^{3}$ \\ ${ }^{1}$ Korea Polar Research Institute, Incheon 21990, Korea \\ (correspondence: jilee@kopri.re.kr) \\ ${ }^{2}$ Korea Institute of Geoscience and Mineral Resources, \\ Daejeon 34132, Korea (gbkim@kigam.re.kr) \\ ${ }^{3}$ New Mexico Institute of Mining and Technology, Socorro, \\ NM 87801, USA, philipkyle1@gmail.com
}

Melbourne volcano is one of the three active volcanoes in northern Victoria Land, Antarctica. The youngest eruption age is estimated as between 1862 and 1922 based on the depth of the ice cap where tephra layers found at the western lower part of the Mt. Melbourne [1]. We collected a large set of recent eruption products including lava, scoria, pumice and englacial tephra in summit and eastern flank area of the Mt. Melbourne. They show a compositional range of trachyandesite and trachyte $\left(53.9-66.5 \mathrm{wt} \% \mathrm{SiO}_{2}\right)$. Here, we present petrological and mineralogical characteristics of them in order to understand evolution of the magma plumbing sytem of the Melbourne volcano. At least three eruption episodes are recognized. The oldest (eruption phase 3) and the youngest (eruption phase 1) events produced bimodal trachyandesitic and trachytic lavas. However, the second eruption phase represented by the summit welded pumice deposit is considered as a product of large explosive eruption occurred at 1280 C.E., and shows a trachytic composition. Eruption phases 3 is recognized only in proximal englacial tephra layers from the flank of the volcano. The youngest eruption material is represented by tarchyandesitic scoria and trachytic pumice, and found on top of the summit craters. The three episodic pyroclastic trachytes show an evolution trend towards systematically decreasing $\mathrm{SiO}_{2}$ contents. Compositions of olivine, pyroxene and feldspar of the three trachytes also show that they have crystallized from more mafic magma towards eruption phase 1 . This can be interpreted as a result of refilling of a felsic magma chamber by a hotter more mafic magma. Hybrid mingling trachytic lava containing angular trachyandesitic scoria fragments also provides an evidence for the existence of a continuous plumbing and interaction system of a trachyandesite-trachyte magma beneath the Melbourne volcano.

[1] Lyon (1986) New Zealand J. Geol. Geophys, 29, 135-135. 